ISSN: 2362-1303 (Paper) | elSSN: 2362-1311(Online)

JOURNAL OF ADVANCED ACADEMIC RESEARCH (JAAR)

Jan 2016

\title{
Sustainable Model of Organic Agriculture: A Case study of Nepalese Farmers
}

\author{
Raj Kumar Banjara, PhD Scholar, Mewar University, Rajasthan, India \\ Meena Poudel, PhD, Research Fellow of Newcastle University, UK
}

\section{Corresponding Author}

Raj Kumar Banjara

Email: rkb.ktm@gmail.com

\section{ABSTRACT}

Epistemology of organic agriculture is logically and practically associated with the conventional farming practices. Organic agriculture can contribute in the social life of people by improving health and ecology. It is even more important for the preservation of natural resources. In relation to the importance of organic agriculture, the main objective of this study was to develop the sustainable model of organic agriculture. The study was based on the inductive approach; qualitative design. Study was conducted in 4 districts of Nepal among the 614 respondents. The result found that there was significant contribution made by the organic agriculture to improve the socio-economic status of farmers as well as to care the relationship between the human being and their environment. Family farming system is the fundamental base for changing trend of agriculture in worldwide practices. There is need to protect and enhance family farming through farmers' cooperative for the sustainability of organic agriculture. The study developed the sustainable model covering the need of infrastructure development, policy improvement, and motivational factors for farmers and changing process of modern agriculture to organic agriculture. The roles of government, non-government, private sectors, individual farmers and consumers are equally important for the sustainability of organic agriculture. The model focuses on the collective effort of all responsible stakeholders. There is need to test the effectiveness of this model.

\section{KEYWORDS:}

Family Farming, Integrated Pest Management, Organic Agriculture, Sustainable model 
ISSN: 2362-1303 (Paper) | elSSN: 2362-1311(Online)

JOURNAL OF ADVANCED ACADEMIC RESEARCH (JAAR)

Jan 2016

\section{INTRODUCTION}

"Organic farming is defined as a form of agriculture, which does not use chemical inputs in its production process, and enhance the biological and ecological processes to promote soil fertility and good health of animals and plants (Gafsi, Le, \& Mouchet, 2010, p. 4)". It involves complete view and it depends on ecological processes, biodiversity as well as cycles adapted to local circumstances rather than the use of external inputs with hostile effects. Its goal is to promote fair associations and a good quality of life for all related components.

The traditional system of agriculture in Nepal was organic but with the change in time, the practices changed more towards inorganic, which is a direct threat to agriculture productivity, environmental quality and human health (Krishna P. Paudyal, 2010).

Tamang et al. (2011, 3 June) writes on the concept and history of organic agriculture in Nepal that "the organic agriculture is a very common word in Nepali agriculture sector. Over a century, traditionally, farmers in hills and mountains are following the farming practice, which is similar to organic farming. However, many of them have no idea that their traditional practice is called organic agriculture (p. 3)". More than that certification process also takes time and farmers do not go for that process. Tamang and her colleagues write on this issue as "because of the lengthy certification process the products produced through organic means do not get recognition as organic products (p. 3)". In the case of development scenario of modern inorganic trends of farming in Nepal, Tamang et al. (2011, 3 June) writes that "There is increasing trends of using inorganic chemicals, terminator seeds and adopting high input technologies. The population growth and demanding cash income to run the household forced farmers to increase their agriculture production including food, therefore farmers started to adopt the modern farming techniques (p. 4)". Time and again there are many reports on the harmful effects of unbalanced and excessive use of chemical fertilizer and pesticides on human as well as animal health and environment. To reduce those hazards, different kinds of environmental friendly agriculture/farming promotion efforts such "alternative agriculture, ecological agriculture/farming, bio-dynamic agriculture, regenerative agriculture, natural farming, permaculture, sustainable agriculture, with organic agriculture (Tamang, Dhital, \& Acharya, Status and scope of organic agriculture in Nepal, 2011, 3 June, p. 5)" are in practice.

An increasing number of reports claim that organic agriculture can be a vehicle for poverty reduction, and empirical research approves a definite relation between organic agriculture, food security and poverty decline in developing country contexts (IFAD, 2003; Araya \& Edwards, 2005; Egziabher, 2005). The Food and Agriculture Organisation (FAO) steered a wide report of organic agriculture's potential to contribute to food security in 2002, concluding that organics is a positive strategy not only for trade, but for sustenance farmers attempting to meet family food necessities and perhaps sell surplus in local markets. Research from numerous developing countries points to lower production costs in organic systems because less external inputs are used (Rosegrant \& Ringler, 2005) and price premiums of up to $300 \%$ may be gained on the international 
market (Setboonsarng, 2006, p. 8). Other studies have found that even without price premiums, farmers are adopting organic agriculture to save costs and achieve viable yields (Scialabba, 2002). Studies also show health improvements for farmers under organic systems. Farmers in India said that symptoms associated with pesticide poisoning reduced after conversion to organics (IFAD, 2005), and a Latin American study showed that farmers perceived themselves to be better after adaptation to organics (IFAD, 2003). On a macro scale, a comparative paper published in 2007 compiled data on crop yield from 293 studies, and found that organic methods could produce enough food on a global per capita basis to sustain the current human population, and possibly an even larger population, without increasing the agricultural land base (Badgley, et al., 2007). Research is still biased towards certified market-led organic approaches, and the literature on the work of numerous organizations promoting organics for subsistence and local productionconsumption networks is poorly developed (Parrott \& Wright, 2007).

Organic Agriculture has a focus on environmental issues and food security. Organic Agriculture claims to provide benefits in terms of environmental protection, conservation of nonrenewable resources, improved food quality, improve health status and the reorientation of agriculture towards areas of market demand. Additionally, organic farming increases the quality of soil, water, air and biodiversity. Soil building practices such as crop rotations, inter-cropping, symbiotic associations, cover crops, organic fertilizers and minimum tillage are central to organic practices. Similarly, the organic agriculture has significant contribution to promote the socioeconomic life of farmers. So, considering the overall benefit of organic agriculture, the study aims to develop the sustainable model of organic agriculture from the study of organic farmers of Nepal.

\section{METHOD}

The study was based on the qualitative research design focusing on the collection of people's perception and practices of organic farming. It had adopted the 'Inductive Approach'; and developed the model on the basis of primary data. The study was done in four districts (Kathmandu, Lalitpur, Bhaktpur and Dhading) of Nepal. The primary respondents were the organic farmers and secondary informants were the experts, policy makers, development practitioners and government authorities. The study was conducted among the total 614 respondents. The study developed the semi-structured types of questionnaires to collect the opinion of respondents. Reliability and validity of instrument was tested by doing the pilot study before the implementation to collect the final data. Purposive sampling technique was adopted to select the respondents. Perceptual data was collected and did the thematic analysis to develop the sustainable model of organic farming. As the limitation of this method, the study had only developed the model but not tested.

\section{RESULT AND DISCUSSION}

The objective of this study was focused to explore the sustainability framework of the organic farming. It is well understood that as the principles of organic agriculture, it significantly 
ISSN: 2362-1303 (Paper) | elSSN: 2362-1311(Online)

JOURNAL OF ADVANCED ACADEMIC RESEARCH (JAAR)

Jan 2016

contribute in the human health and environment so it is necessary to promote the organic farming. The study had identified some challenges of organic farming as experienced by the farmers; high production cost $\&$ high price of products, low quantity of product, no adequate market, certification problems ...etc. In spite of all these problems, consumers are conscious on their health and environment so from the individual level to Government level, they should contribute their effort and should honestly paly their roles and responsibilities to sustain the organic farming so that human health and environmental pollution can be addressed.

Sustainable organic agriculture should meet the needs of the present generation without jeopardizing the needs of future generations. It must also be economically sustainable to the farmer, and to society as a whole. Global warming is creating increasingly unpredictable weather patterns in the world. Organic farms have higher yields than conventional crops when under stress caused by drought, heat, excessive rain or unseasonably-cold weather. As well, organic crops have higher pest and disease resistance.

The study had conducted the face to face interview with the subject experts of organic agriculture to explore the strategic ideas of sustainability of organic agriculture in Nepal. Experts' opinion showed the various opportunities of organic agriculture in Nepal which also ensured the need of sustainable model of organic agriculture.

"Organic needs the separate organization having with competent manpower, adequate resources and effective management. Organic should be one main area of Agriculture Ministry. Government should be careful in management of main 3 sector of organic agriculture. These are: i) Software: establish Research Education, Training, promotion of knowledge and information, ii) Hardware: availability of organic fertilizer, seeds, land, storage, lab, transportation, auction market ...etc and iii) Market: coordination between and within the national and international market for the greater sells and better price. If these 3 areas can be strengthen then organic agriculture can be sustained which can develop the growth of Nation also." - Basanta Ranabhat, Chairman, Organic Certification Nepal Pvt. Ltd (Nepal Govt. approved national organic certifying agency in Nepal)

"There is need of separate Board of management and promotion of Organic agriculture which can increase the quantity of Export in International market. Developed countries are promoting the organic agriculture because of their increasing consciousness of climate change, environmental degradation and caring of health. Promotion of organic training and certification can be managed through the single Centre." - Kumud Shing, Director, Alpine Coffee Estate

Prakash Shrestha, Director, Olla Coffee Center said that there was need of clear policy and program of Government to make the organic agriculture sustainable.

Dhakeswor Ghimire, Founder, Nepal Organic Coffee Producers Association shared his ideas by saying that there was need of separate entity to manage the organic system. Board should be non- 
ISSN: 2362-1303 (Paper) | elSSN: 2362-1311(Online)

JOURNAL OF ADVANCED ACADEMIC RESEARCH (JAAR)

Jan 2016

political and result oriented. Government should aware the customers for the maximum use of organic products of Nepal and needed to control export of non-organic goods from the international market.

The need of separate Board for the management of organic agriculture was asked by many experts during the study. Khadga Bhakta Paudel, Senior Scientist (Rtd.), Senior Scientiest (Rtd.), Nepal Agriculture Research Council (NARC) also said that Nepal Government had to formulate the separate Organic Board who could manage the marketing, certification, monitoring, research, provides or hires required technical experts, develop the 5 or 10 years strategies plan of production. Promotional activities could ensure the quality of organic goods in international market. Non-governmental organizations, private sectors and farmers should support the program of Nepal Government so that contemporary situation of 'Push and Sell' could be changed into cost effective organic farming

Different perception was found regarding the need of separate Organic Board. According to the Dr. Surya Pandey, Soil Scientist, Kiwi Research Center, Kavre, government could manage the promotion and monitoring of organic agriculture from the existing organizational system. Similarly, Dr. Bhartendu Mishra - Member of National Planning Commission, Aashis Thapamagar - Manager of Nativ Multipurpose Pvt. Ltd. Kathmandu and Dipak Prasad Koirala Chairman of Nepal Junar Cooperatives Central Federation Ltd. Kathmandu also supported the statement of Dr. Pandey by saying that Nepal Government and private sectors should be responsible to promote the organic agriculture. They also said "government should make the law against the pesticide and chemical fertilizer users and need to prepare the strategic plan of organic production. Government should establish the organic fertilizer production factory, train the farmers, mobilize the technical manpower in community, provide the seeds and loan facilities."

Manoj Acharya - Coordinator of Participatory Guarantee System, Kathmandu emphasized the need of clear policy of government, separate organic board, dissemination of organic guideline, monitoring, marketing, certification, coordination and research to sustain the organic agriculture in long run. The opinion of Mr. Acharya was supported by the Hiralal Rokaya -Nayapati Multipurpose Agro Firm, Kathmadu and Dilip Rai - Owner, Nepal Green and Specialty Tea Pvt. Ltd.

Dr. Yubabdhoj G.C - Director General, Department of Agiculture, Ministry of Agriculture, Nepal showed the need of production of organic fertilizer and pesticide in Nepal. He said "Agricultural diversification is important for the Economic development. Organic agriculture is suitable in Nepalese environment and beneficial for the Nepalese farmers also from the socio-economic perspective."

From the overall analysis of qualitative and quantitative data of the study, the following sustainability framework of organic agriculture is recommended: 
ISSN: 2362-1303 (Paper) | elSSN: 2362-1311(Online)

\section{JOURNAL OF ADVANCED ACADEMIC RESEARCH (JAAR)}

Jan 2016 
ISSN: 2362-1303 (Paper) | elSSN: 2362-1311(Online)

JOURNAL OF ADVANCED ACADEMIC RESEARCH (JAAR)

Jan 2016

Figure 1: sustainability framework of organic agriculture

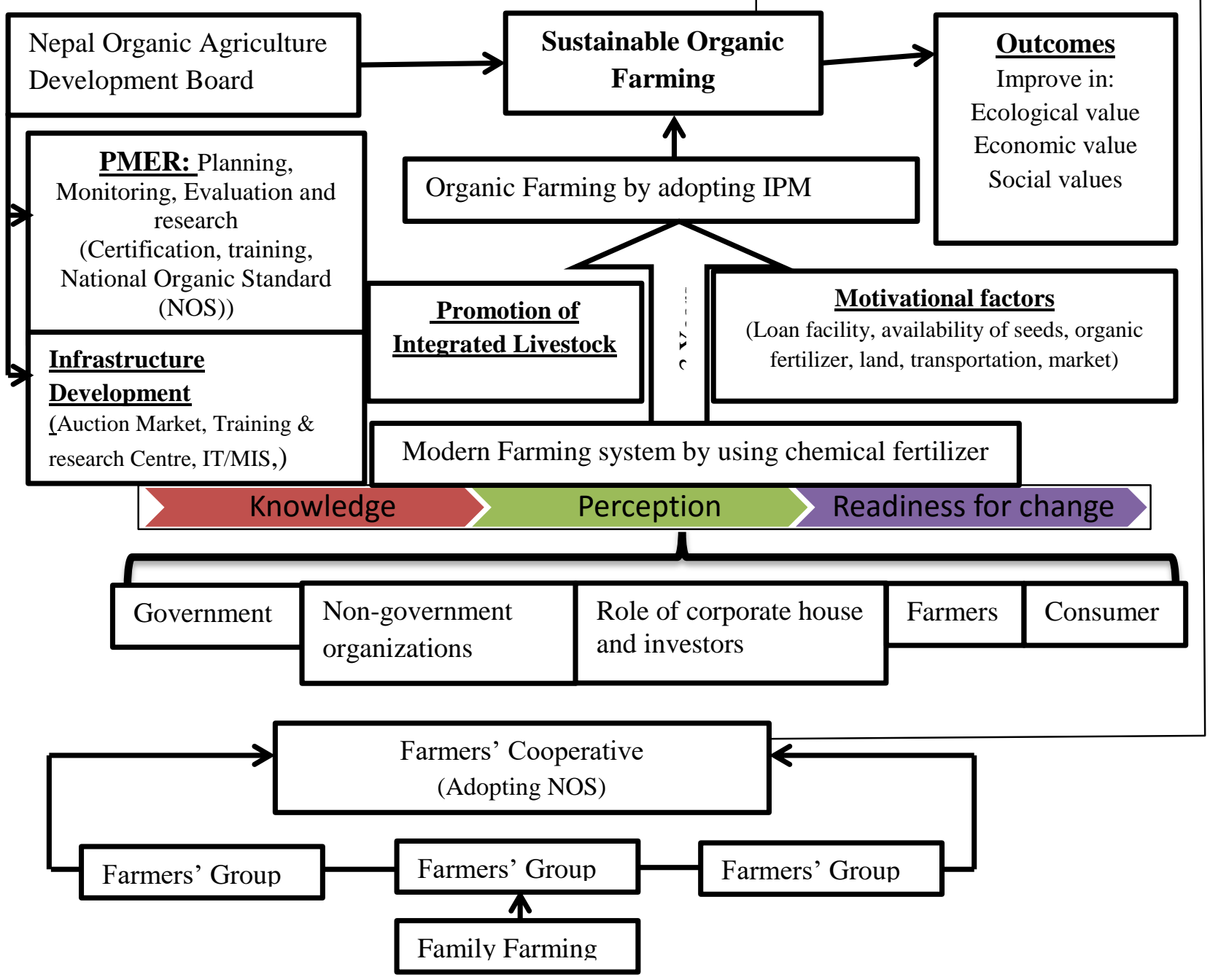

The above conceptual idea of sustainable organic farming shows the interrelationship between the different factors and actors which can play the vital roles in sustaining organic farming. The model explains about the process of readiness for the change. It says that when any new technology comes in the society, people first gather knowledge on that particular technology then thinks about the cost and benefit of it and finally decides to accept or to reject that technology. Here, the model focuses on the need of change in the modern farming system through the IMP system. It assumes that if farmers will practice 3 years of farming with IPM it will make easy to transfer into pure organic farming. The model also emphasize on the management of separate organic board that can overall manage the requirement of software and hardware part of organic farming. There is need of motivational factors and promotion of integrated livestock which can also support to sustain the practice of organic farming. The previous studies on agricultural system and this study found that there was and still is family farming practice in Nepal. Family farming system is more 
ISSN: 2362-1303 (Paper) | elSSN: 2362-1311(Online)

JOURNAL OF ADVANCED ACADEMIC RESEARCH (JAAR)

Jan 2016

individual centered. Family decides about the farming practices on the basis of their past experiences, socio-cultural values and norms.

Various previous literatures have highlighted the importance and contribution of 'Family Farming' in the promotion of agriculture and development of society. According to the Agence Française de Développement \& Sustainable Development Department (SDD), family farming can address the challenges of food security and employment in future world. It said that "in 2050, the planet will be populated by 9 billion inhabitants. Most population growth will take place in developing countries and cities, which will require more resources. Dwindling energy supplies and climate change calls for new models for sustainable agriculture. Family farms are capable of meeting these challenges and have demonstrated their capacity for innovation and adaptation over centuries. They will however need support, particularly in countries in the global South, from ad hoc policies and mechanisms (such as professional training and land tenure security)" (AGENCE FRANÇAISE DE DÉVELOPPEMENT \& SUSTAINABLE DEVELOPMENT DEPARTMENT (SDD), 2012, p. 2). In Nepalese practice, farmers are individually working and promoting their goods which will be the problem to compete in market and sustain in long run. There are also some limitations of 'family farming'; limited access to credit, marginal position in the value chain, lack of infrastructure, limited access to information, and a marginalized role in international fora and development agendas which was accepted by the Cinzia Pagni, WFO (The World Farmers' Organisation (WFO), 2013). Family Farming also crates the problem of organic certification as they have to pay separately for each grower. So, this model recommended developing the Farmers' Group which can advocate the issue of organic farmers among the concerned authorities. Gradually, the Farmers' Group should be included and managed by the Farmers' Cooperative. It will be more formal organization for farmers and can support to manage the problem. For instance, the cooperative can collectively certify the product as organic and also provide the technical trainings, education on pest management, crop protection and to enhance the overall productivity and crops yield. Farmers' Cooperative should promote the productivity and capacity of family farming because 'family farming is the basic building blocks of sustainable organic agriculture'. All these effort shown in the model can be the support to sustain the organic farming.

The model has clearly mentioned the roles and responsibilities of potential actors who can play the vital roles to sustain the organic agriculture in Nepal. The detail roles are explained below:

Role of Government: government should be more careful about the planning of sustainable development of organic agriculture, easy loan support to farmers, promotion of PGS, and formulation of 'organic agriculture board', establishing the 'Training and Research Centre' and auction market. Besides that government should facilitate to develop the networking with the international market of organic products. Monitoring and supervision should be strong and government should award to those who will do better and punishment should be given to those who will do intentional mistake. 
Role of Non-governmental organization: non-government organizations should involve in promotion of training and dissemination of organic agriculture. They should involve awareness rising to farmers and consumers about organic agriculture.

Role of corporate house and investors: they can contribute by investing in the field of organic agriculture and can develop the networking in international market. They should be responsible to ensure the quality of organic agriculture by supporting for organic certification and using the trade mark of organic.

Role of Farmers: Organic farmers diversify their businesses by growing several crops at one time, often having both livestock and field crops, and sometimes value-added enterprises as well. The diversification reduces economic risk. Also enterprise diversification makes it easier for farmers to be more self-sufficient in terms of nutrients, livestock feed, soil organic matter and energy. The most challenging time is the transition period as farmers switch from conventional to organic agriculture. During this period, the price premium is absent and yields are low. Sometimes farmers can receive a minor price premium for transitional production, with a price higher than conventional prices, but lower than the certified organic prices. Some farmers find that the yields rebound within just a few years; this is most likely to happen with farmers who were using only minimal inputs. Other farmers, who were very dependent on herbicides, fertilizers and pesticides, found that it takes a long time for their yields to recover

Role of Consumers: consumers should be aware about the benefit of organic agriculture in health, environment and socio-economic status of people. Consumers should give the first priority to purchase the pure Nepalese organic products and must involve in the disseminating information and knowledge of organic products.

Regarding the sustainability approach of agriculture, various previous studies has also explored the different way and techniques of sustainability. Japanese philosopher Osamu Soda, in the recently released book Philosophy of Agricultural Science, describes a "process for increasing total welfare or realizing comprehensive values." The concept provides for balance between ecological values, economic values, and life values in the context of "ba," or place. It is in the local that farmers, research, and policy come together in the context of human community to solve problems and achieve goals (2006).

In coming years, nations, local communities, and individuals will have to make many difficult ethical decisions concerning the competing requirements of agricultural production, ecosystems, economics, and social justice (Oliveira, Vaughan, \& Rykiel, 2005). Locally based agriculture can provide ecosystem services that are of great value in particular regions. For example, in the Minnesota River valley, impacts from row crop production have made the river one of the 20 most endangered waterways in America (Mulla \& Mallawatantri, 1997). 
There are numerous studies on possibilities of organic agriculture in developed and under developed countries. How is the feasibility of organic agriculture in under developed countries like Nepal? Urs Niggli (2015) writes on that:

While the crop productivity of organic farms appears to be $0.7-0.8$ of that of intensive farms in temperate zones, the yield ratio in marginal regions of Africa where subsistence farming is still widely spread, has been found to be in favour of organic farms. Hence, in resource- and income-poor countries, organic farming seems to offer an appropriate and low-cost way to increase productivity and to improve farm livelihood. (p. 1)

As Niggli has stated that possibility of organic agriculture is easier in those countries where still the practice of agriculture for subsistence exist. Nepalese farmers are also practicing subsistence farming.

Family farming is another way of applying alternative agriculture. This type of model occupies limited area and generates job and promotes for organic production. Saldanhaa et al. (914 August 2015) writes on the possibility and viability of family farming for sustainable farming:

Family farming is featured as the one growing in which the aim of tasks on the premises is decided by both the producer and his family. Family work force is superior to hired work and the area of the property is within a limit set for each region of the country. Such way of farming has demonstrated characteristics of adaptation and feasibility, it is not only a way of generating jobs and income in the rural areas but also a way of developing sustainable production. (p. 1)

This type of alternative agriculture is suitable even in Nepal because Nepal has not yet practiced commercialized and industrialized farming. Still family farming is practiced in rural areas. Such model promotes for sustainable farming.

The concept of family farming covers various elements. From a sociological perspective, family farming is associated with family values, such as solidarity, continuity and commitment; in economic terms, family farming is identified with specific entrepreneurial skills, business ownership and management, choice and risk behavior, resilience and individual achievement.

Family farming is often more than a professional occupation because it reflects a lifestyle based on beliefs and traditions about living and working (European Commission, 2015). Family farming represents the social base for most developing countries and constitutes the main form of agricultural organization worldwide. It contributes to both domestic and international markets. Family farming thus accounts for almost $80 \%$ of global food production, $98 \%$ of food production in Sub-Saharan Africa and almost all cotton, cocoa and coffee production worldwide. Covering around $40 \%$ of the planet's agricultural land, family farms is the number one source of employment worldwide. Yet they also paradoxically account for the majority of farmers living in poverty and food insecurity (AGENCE FRANÇAISE DE DÉVELOPPEMENT \& SUSTAINABLE DEVELOPMENT DEPARTMENT (SDD) , 2012) 
Saldanhaa et al. (9-14 August 2015) have proposed a model for family farming sustainable development, which is called AGROINDEX. This model aims to contribute to:

Monitor the aspects of production, productivity, sustainability and human factors by the farmers themselves thus contributing in the search for sustainability and empowerment of families and the communities respectively; Decision-making by the family farmers that contributes to improve the production management on sustainable bases; Subside decisionmaking of the fomentation institution managers concerning the need of investments and results; improvement in the management of projects of qualification and fomentation projects enabling the comparison of indicators before and after the interventions.; Release a set of information which will subside the managers to formulate and implement public policies that allow adequate conditions for local development. (p. 6)

Such model seems to be worthwhile even in the case of Nepal. The nature of farming in Nepal resembles as mentioned by Saldanahaa et al.

"Organic agriculture can contribute to meaningful socio-economic and ecologically sustainable development, especially in poor countries (Kilcher, 2007, p. 31)". This is still difficult, as on the one hand the application of organic principles, which means effective managing of local resources for example, local seed varieties, manure, etc. are cost efficiency. On the other hand, the market for organic products at local and international level has great growth prospects and offers creative producers and exporters in those areas then it creates excellent opportunities to improve their income and living conditions.

Organic products gain more income than conventional one. Kilcher (2007) states, "Certified organic products provide access to attractive local and international markets for developing countries, while the producers generate higher incomes. In addition, due to long-term contracts, income is generated more continuously than in conventional trade (p. 43)".

There are many more possibilities and benefits of adopting organic agriculture. However, farmers usually experience a decline in harvests after leaving the use of artificial inputs and converting their farm to organic production. "Once the agroecosystem is restored and organic management systems are fully implemented, the farmers get good harvests" (Kilcher, How organic agriculture contributes to sustainable development, 2007, p. 41). The development of crops fluctuates, and depends on inherent biological factors and natural resources, the farmer's expertise on the extent to which synthetic inputs were used under previous conventional management. If conversion to organic takes place on the basis of a low-input system, which is often the case for poor farmers in developing countries, yields under organic management tend to be more stable compared to the previous management system (Kilcher, How organic agriculture contributes to sustainable development, 2007, p. 41).

A sustainable way requires creating holistic, multifunctional farming systems based on the needs, limitations, and resources of communities - human and ecological. Agriculture based on a 
series of isolated components - crops separate from livestock, farmers distanced from consumers, farming separated from culture and production systems disrupting ecological processes-won't sustain agriculture in the future. The future of food, the land, and society requires making agriculture as a whole.

\section{CONCLUSION}

Organic agriculture was found important from the perspective of health and environment. From the study, it was found that more than $90 \%$ respondents were satisfied from the income of organic products and they were using the income for the promotion of child education, for health facilities and in building and renovating houses. People perceived the need for sustainability of organic agriculture in Nepal because it lays down the modern agriculture with the high use of pesticides and chemical fertilizer. There is high chance for sustainability of organic agriculture in Nepal because the conventional farming practices were more similar to the organic agriculture and also there is family and small-scale farming practices in Nepal. Family decides the needs and promotion of agriculture on the basis of their cultural values, social norms and practices. Family and smallscale farming are inextricably linked to world food security. Family farming preserves traditional food products, by contributing to a balanced diet and safeguarding the world's agro-biodiversity and the sustainable use of natural resources. But there were some difficulties of family farming so this study recommended developing the Farmer's Cooperative which can contribute to address the various issues raised among the 'family farming' because 'family farming is the basic building blocks of sustainable organic agriculture'. The sustainable model also promoted to manage the integrated livestock practices because farmers should be encouraged by providing the motivational incentives by Government and non-governmental organization. The model clearly explained the roles and responsibilities of different actors to sustain the organic agriculture. Among them, government should take the serious lead role to promote and mobilize the resources for the sustainability of organic agriculture. If organic agriculture can be sustained, then finally it will increase the Ecological value, Economic value and Social values. As the limitation of this study, the study has developed the sustainable model on the basis of primary and secondary data, so the researcher can further test the model to measure its effectiveness.

\section{BIBLIOGRAPHY}

AGENCE FRANÇAISE DE DÉVELOPPEMENT \& SUSTAINABLE DEVELOPMENT DEPARTMENT (SDD) . (2012). Family farming. France: Agence Française de Développement (AFD) .

Agri statistics Section. (2011/2012). STATISTICAL INFORMATION ON NEPALESE AGRICULTURE. Agri-Business Promotion and Statistics Division, Ministry of Agricultural Development. Kathmandu, Nepal: Government of Nepal. 
ISSN: 2362-1303 (Paper) | elSSN: 2362-1311(Online)

JOURNAL OF ADVANCED ACADEMIC RESEARCH (JAAR)

Jan 2016

Agricultural Commodities Export Prommotion Program. (2014). Organic Agriculture Production, Certification, Direction, Guidlines. Lalitpur: Agricultural Commodities Export Prommotion Program.

Agriculture Policy Research and Analysis Department, Govt of Nepal. (2015). Agricultural Policy. Kathmandu, Nepal: Agriculture Policy Research and Analysis Depertment, Govt of Nepal.

Agriculture Policy Research and Analysis Depertment, Govt of Nepal. (2015). Agricultural Policy. Kathmandu, Nepal: Agriculture Policy Research and Analysis Depertment, Govt of Nepal.

Altieri, M. (2002). Non-certified organic agriculture in developing countries. Rome: Rome: Food and Agriculture Organisations of the United States.

Anandkumar, S. (1998). Anandkumar, S. (1998). Motivating farmers to convert to organic farming and strategies for organic extension. , 18, 21-22. Ecology and Farming, 22, 21-22.

Anjana Malla Pradhan, C. B. (2015, April ). An Alternative Source of Livelihood: Socio-Economic Analysis of Organic Vegetable Growing in Nepal: A Case Study. International Journal of Science and Research (IJSR), 4(4), 924-928.

Araya, H., \& Edwards, S. (2005). Successes in Sustainable Agriculture: Experiences from Tigray, Ethiopia. Third World Network.

Badgley, C., Moghtader, J., Quintero, E., Zakem, E., Chappell, M., Aviles-Vasquez, K., et al. (2007). Organic Agriculture and the Global Food Supply. Renewable Agriculture and Food Systems, 22(2), 86-108.

Beban, A. (2008). Organic Agriculture: An Empowering Development Strategy for Small-Scale Farmers? A Cambodian Case Study.

Bhat, B. R. (2009, June). OPPORTUNITY AND CHALLENGE OF ORGANIC CERTIFICATION SYSTEM IN NEPAL. The Journal of Agriculture and Environment, Vol:10, 124-128.

Bhatta, G. D., Doppler, W., \& KC, K. B. (2009, June). POTENTIALS OF ORGANIC AGRICULTURE IN NEPAL. The Journal of Agriculture and Environment, 10, 1-11.

Bjørkhaug, H. (2012). Exploring the Sociology of Agriculture: Family Farmers in Norway - Future or Past Food Producers? In D. D. Erasga, Sociological Landscape - Theories, Realities and Trends (pp. 284-304). Europe \& China: InTech Europe \& China.

BOODY, G., \& DeVORE, B. ( 2006 , October ). Redesigning Agriculture. BioScience, 56(10), 839-845. 
ISSN: 2362-1303 (Paper) | elSSN: 2362-1311(Online)

JOURNAL OF ADVANCED ACADEMIC RESEARCH (JAAR)

Jan 2016

Buhler, D. D., L. M., \& Obrycki, J. J. (2000). Theoretical and practical challenges to an IPM approach to weed management. Weed Science, 48(3), 274-280.

Bürger, J., de Mol, F., \& Gerowitt, B. (2012). Influence of cropping system factors on pesticide use intensity - A multivariate analysis of on-farm data in north east germany. European Journal of Agronomy, 40(10), 54-63.

Cardina, J., Webster, T. M., Herms, C. P., \& Regnier, E. E. (1999). Development of weed IPM: Levels of integration for weed management. Journal of Crop Production, 2(1), 239-267.

Carolan, M. S. (2005). Barriers to the adoption of sustainable agriculture on rented land: An examination of contesting social fields. Rural Sociology, 70-3, 387-413.

CEDAC. (2007). Campaign to Promote Ecological Agriculture and Local Products. Siem Reap: CEDAC.

Central Bureau of Statistics. (2011). Agricultural Census 2011. National Planning Commission Secretariat. Kathmandu, Nepal: Government of Nepal.

Central Bureau of Statistics. (February, 2014). National Population and Housing Census 2011. National Planning Commission Secretariat. Kathmandu, Nepal: Government of Nepal.

Ceylan, I. C., Koksal, O., \& Kutlar, I. (2010). Determination of effective factors on adoption of integrated pest management practices. Journal of Environmental Protection and Ecology, 11(2), 709-717.

CGAP. (2005). About Microfinance. Retrieved from www.cgap.org

Chaves, B., \& Riley, J. (2001). Determination of factors influencing integrated pest management adoption in coffee berry borer in colombian farms. Agriculture Ecosystems \& Environment, 87(2), 159-177.

Cleveland, b. G. (1999, November 1). Development Theory: ICPD. Retrieved Jun 24, 2015, from The International Center for Peace and Development (ICPD): http://www.icpd.org/development_theory/SocialDevTheory.htm

Courville, S. (2006). Organic Standards and Certification. In S. P. Kristiansen, A. Taji, \& J. Reganold, Organic Agriculture: A Global Perspective. Australia: CSIRO.

Cresswell, J. W., \& Clark, V. L. (2011). Designing and conducting Mixed Methods Research (Vol. 2nd). USA: SAGE Publication Inc. 
ISSN: 2362-1303 (Paper) | elSSN: 2362-1311(Online)

JOURNAL OF ADVANCED ACADEMIC RESEARCH (JAAR)

Jan 2016

Dettmann, R. L., \& Dimitri, C. (2010). Dettmann, R. L., \& Dimitri, C. (2010). Who's buying organic vegetables? Demographic characteristics of US consumers. Journal of Food Products Marketing, 79-91.

Dimitri, C., \& Oberholtzer, L. (2009, September). Marketing US organic foods: Recent trends from farms to consumers. USDA Economic Research Service.

Dolan, C., \& Sorby, K. (2003). Gender and employment in high-value agriculture industries. Washington D.C: World Bank.

Duesing, B. (2014, June 14). Retrieved July 16, 2015, from CTNOFA: http://ctnofa1982.blogspot.com/2014/06/organic-integrated-pest-management-ipm.html

Egziabher, T. (2005). Let local communities continue with organic agriculture to feed Africa. Ecology and Farming 37-41, 37-41.

Elliott, K. G. (2015, May 24). Articles: LIVESTRONG.COM. Retrieved September 10, 2015, from Demand Media, Inc.: http://www.livestrong.com/article/139831-the-effects-fertilizerspesticides/

EuropeAid. (June 2012). ORGANIC AGRICULTURE: Information Note. EUROPEAN COMMISSION.

European Commission . (2015, April 22). Agriculture and Rural Development Family farming. Retrieved February 27, 2016, from European Commission : http://ec.europa.eu/agriculture/family-farming/index_en.htm

FAO. (2002). Organic Agriculture and Food Security. FAO, Rome. . Retrieved from www.fao.org

FAO. (2009). How to feed the world in 2050. Rome: FAO.

FAO, Food and Agriculture Organization of the United Nations. (2007). 2007Paying farmers for environmental services. Rome: FAO.

FiBL \& IFOAM. (2015). The World of Organic Agriculture: Statistics and emerging trends. Switzerland: FiBL \& IFOAM Organics International.

Gafsi, M., Le, T. S., \& Mouchet, C. (2010). Organic farming is it a sustainable agriculture ? Innovation and Sustainable Development in Agriculture and Food, 1-12.

Gajurel, D. ( 2015, January 26). Retrieved September 4, 2015, from Nepal Polity: http://nepalpolity.com/?p=5515\#sthash.brSS9r05.dpbs 
ISSN: 2362-1303 (Paper) | elSSN: 2362-1311(Online)

JOURNAL OF ADVANCED ACADEMIC RESEARCH (JAAR)

Jan 2016

Gay, L. (1987). Eductional research: competencies for analysis and application. Columbus: Merrill Publication Company.

Ghimire, A., \& Khatiwada, B. P. (2001). Use of Pesticides in Commercial Vegetable Cultivation in Tandi, Eastern Chitwan, Nepal . Chitwan, Nepal : Rampur Campus .

GoN:Agribusiness Promotion and Marketing Development Directorate. (2013 (B.S. 2070) ). Organic Agriculture production and Certification directives. Agri-products Export Promotion Program, Department of Agriculture. Hariharbhawan, Lalitpur, Nepal: http://www.agribiz.gov.np/.

Greene, J. C. (1997). Defining and describing the paradigm issue in mixed-method evaluation. In J. C. (Eds.), Advances in mixed-metho evaluation: The challenges and benefits of integrating diverse pradigms (pp. 1-18). San Francisco: Jossey-Bass.

Guthman, J. (2000). Agrarian Dreams: The Paradox of Organic Farming in California. Berkeley: University of California Pres.

Halweil, B. (2005). Cambodia Goes Organic. World Watch, 18(2), 3-4.

Haydu, J. (2011). Cultural modeling in two eras of US food protest: Grahamites (1830s) and organic advocates (1960s-70s). Social Problems, 58(3), 461-487.

Helga Willer, J. L. (2014). The World of Organic Agriculture 2014: Summary. Switzerland: Research Institute of Organic agriculture (FiBL), Frick, International Federation of organic movement (IFOAM), Bonn.

Hernandez, A., \& Media, D. (2015). Food: SFGATE. Retrieved September 10, 2015, from SFGATE: http://healthyeating.sfgate.com/fruits-vegetables-important-4703.html

Holt, G., \& Reed, M. (2006). Sociological Perspectives of Organic Agriculture: From Pioneer to Policy. London: CAB Internationa.

Hughner, R. S., McDonagh, P., Prothero, A., Shultz, I. I., \& Stanton, J. (2007). Who are organic food consumers? A compilation and review of why people purchase organic food. Journal of Consumer Behaviour, 6(2-3), 94-110.

Hughner, R. S., McDonagh, P., Prothero, A., Shultz, I. I., Clifford, J., \& Stanton, J. (2007). Who are organic food consumers? A compilation and review of why people purchase organic food? Journal of Consumer Behaviour, 94-110.

IFAD. (2003). The adoption of organic agriculture among small farmers in Latin America and the Caribbean: Thematic Evaluation. IFAD, Rome. Retrieved from www.ifad.org 
ISSN: 2362-1303 (Paper) | elSSN: 2362-1311(Online)

JOURNAL OF ADVANCED ACADEMIC RESEARCH (JAAR)

Jan 2016

IFAD. (2005). Organic Agriculture and Poverty Reduction in Asia. Retrieved from www.ifad.org

IFOAM. (2015). What is organic?:The Organic Information Hub. Retrieved July 15, 2015, from The Organic Information Hub: http://infohub.ifoam.bio/en/faq-organic-agriculture

Ikerd, J. (1993). Two related but distinctly different concepts: organic farming and sustainable agriculture. Small Farm Today, 10(1), 30-31.

Janz, K., Shanxi, T., \& Jacobi, P. (2003). Development of Biological Agriculture in Poverty Stricken Areas of the P.R. of China. Bonn: GTZ.

Jasinski, J., Eisley, B., Gastier, T., \& Kovach, J. (2001). Scoring IPM adoption in ohio: It really adds up. . Journal of Extension, 39(5), 345-367.

John W. Cresswell, \&. V. (2011). Designing and conducting Mixed Methods Research (2nd Eds.). USA: SAGE Publication Inc.

Kaine, G., \& Bewsell, D. (2013). Adoption of integrated pest management by apple growers: The role of context. International Journal of Pest Management, 59(3), 255-265.

KC, B., Bhattrai, P., Dahal, S., Subedi, M. S., Shrestha, A. K., \& Tamang, K. (July 19, 2012). Physical Monitoring Report of Nepalese workers in Malaysia. Ministry of Foreign Employment, Department of Foreign Employment. Kathmandu, Nepal: Government of Nepal.

Kilcher, L. ( 2007). How organic agriculture contributes to sustainable development. JARTS, Supplement, 89 , 31-49.

Kilcher, L. (2007). How organic agriculture contributes to sustainable development. JARTS, 89, $31-49$.

Kotschi, J. (2003). Alter Organic - Local Agendas for Organic Agriculture in Rural Development. AGRECOL.

Krishna P. Paudyal. (2010). Country Report Presented in ANSOFT Workshop held on 29-30 November, 2010 in Suwon, Korea. Asian Network for Sustainable Organic Farming Technology (ANSOFT) Workshop. Suwon, Korea: Asian Food \& Agriculture Cooperation Initiative.

Kristiansen, P., \& Merfield, C. (2006). Overview of Organic Agriculture. In P. Kristiansen, A. Taji, \& J. Reganold, Organic Agriculture: A Global Perspective. Australia: CSIRO: Collingwood,. 
ISSN: 2362-1303 (Paper) | elSSN: 2362-1311(Online)

JOURNAL OF ADVANCED ACADEMIC RESEARCH (JAAR)

Jan 2016

Lamine, C. (2011). Transition pathways towards a robust ecologization of agriculture and the need for system redesign. cases from organic farming and IPM. Journal of Rural Studies, 27(2), 209-219.

Lamine, C. (2011). Transition pathways towards a robust ecologization of agriculture and the need for system redesign. cases from organic farming and IPM. Journal of Rural Studies, 27(2), 209-219.

Lampkin, N. (2002). Organic Farming. UK: Old Pond.

Li, J., Zepeda, L., \& Gould, B. W. (2007). The demand for organic food in the US: An empirical assessment . Journal of Food Distribution Research, 35-41.

Liebman, M., Mohler, C., \& Staver, C. (2001). Ecological management of agricultural weeds. Cambridge University Press.

Llewellyn, R. S. (2007). Information quality and effectiveness for more rapid adoption decisions by farmers. Field Crops Research, 104(3), 148-156.

Lofland, J., \& Lofland, L. H. (1995). Analyzing Social Settings: A Guide to Qualitative Observation and Analysis (3rd Edt.). UK: Wadsworth.

Lohr, L., \& Park, T. (2002). Choice of insect management portfolios by organic farmers: Lessons and comparative analysis. Ecological Economics, 43(1), 87-99.

Magdoff, F., Bellamy Foster, J., \& Buttel, F. (2000). Hungry for Profit: The Agribusiness Threat to Farmers, Food, and the Environment. New York: Monthly Review Press.

Malone, S. J., \& Pheasant, S. (2004). Determining adoption of integrated pest management practices by grains farmers in virginia. . Journal of Extension, 42(4), 102-113.

Mulla, D., \& Mallawatantri, L. (1997). Minnesota River Basin Water Quality Overview.. Saint Paul (MN). University of Minnesota Extension Service, FO-7079-E.

Neuman, W. L. (2012). Social Research Methods: Quantitative and Qualitative Approaches (6th Eds.). New Delhi, India: Pearson Education Inc.

Niggli, U. (2015). Organic Farming, Prototype for Sustainable Agricultures. (S. Bellon, \& S. Penvern, Eds.) New York: Springer Dordrecht Heidelberg.

Norland-Tilburg, E. V. (1990). Controlling error in evaluation instruments. Journal of Extension, 28(2). 
ISSN: 2362-1303 (Paper) | elSSN: 2362-1311(Online)

JOURNAL OF ADVANCED ACADEMIC RESEARCH (JAAR)

Jan 2016

Norse, D., \& Tschirley, J. (2003). Agriculture and the environment: Changing pressures, solutions and trade-offs. In J. Bruinsma, World Agriculture: Towards 2015/2030: An FAO Perspective (pp. 331-356). London: Earthscan publications and FAO. .

Oliveira, M. D., Vaughan, B., \& Rykiel, E. (2005). Ethanol as fuel: Energy, carbon dioxide balances, and ecological footprint. BioScience, 55, $593-601$.

One Country. (2013). Retrieved September 7, 2015, from Bahá'í International Community: http://www.onecountry.org/story/importance-agriculture

Owen. (2005). Owen. (2005). Farming claims almost half earth's land, new maps show. National Geographic. Retrieved from http://news.nationalgeographic.com/news.

Padel, S. ( 2001, January). Conversion to Organic Farming: A Typical Example of the Diffusion of an Innovation? Sociologia Ruralis: European Society for Rural Sociology, 41( 1), 4061.

Parrott, N., \& Wright, J. (2007). Influencing Attitudes of Public Institutions Towards Organic Agriculture as a Means of Promoting Food Security, . Retrieved from www.ifoam.bio

Poudel, K. L. (18-24 August, 2012). Comparing technical efficiency of organic and conventional coffee farms in Nepal using data envelopment analysis (DEA) approach. International Association of Agricultural Economists (IAAE) Triennial Conference, (pp. 1-32). Foz do Iguaçu, Brazil, .

Pretty, J. (2002). Lessons from certified and non-certified organic projects in developing countries. In N. Scialabba, \& C. Hattam, Organic Agriculture, Environment and Food Security. Rome: FAO.

Puente, M. D., \& Forkner, R. E. (2011). Assessing integrated pest management adoption: Measurement problems and policy implications. Environmental Management, 48(5), 10131023.

Radhakrishna, R. B., Francisco, C. L., \& Baggett, C. D. (2003). An analysis of research designs used in agricultural and extension education. 30th National Agricultural Education Research Conference, , (pp. 528-541).

Rao, C. A., Rao, M. S., Srinivas, K., Patibanda, A. K., \& Sudhakar, C. (2011). Adoption, impact and discontinuance of integrated pest management technologies for pigeon pea in south india. Outlook on Agriculture, 40(3), 245-250.

Rao, C. N. (2008). Sociology: principles of sociology with an Introduction to Social Thought. Ram Nagar, New Delhi: S. Chand \& Company Ltd. 
ISSN: 2362-1303 (Paper) | elSSN: 2362-1311(Online)

JOURNAL OF ADVANCED ACADEMIC RESEARCH (JAAR)

Jan 2016

Riemens, M. M., Groeneveld, R. M., Kropff, M. J., Lotz, L. A., Renes, R. J., Sukkel, W., et al. (2010). Linking farmer weed management behavior with weed pressure: More than just technology. Weed Science, 58(4), 496-504.

Rigby, D., \& Caceres, D. (2001). Organic farming and the sustainability of agricultural systems. Agricultural Systems, 68, 21-40.

Rogers, E. (1995). Diffusion of innovations (4th edition). New York: The Free Press.

Rogers, E. (2003). Diffusion of innovations (5th ed ed.). New York: Free Press.

Rosegrant, M., \& Ringler, C. A. (2005). Agriculture and achieving the Millennium Development Goals. Washington DC: Agriculture and Rural Development Department, World Bank.

SAHIN, I. ( 2006, April). DETAILED REVIEW OF ROGERS' DIFFUSION OF INNOVATIONS THEORY AND EDUCATIONAL TECHNOLOGY-RELATED STUDIES BASED ON ROGERS' THEORY. The Turkish Online Journal of Educational Technology - TOJET , 5 (2), 14-23.

Saldanhaa, M. C., Carvalhob, R. J., Silvac, E. D., Meloa, C. d., \& Medeiros, M. B. (9-14 August 2015). Proposal of a methodology for conception sustainable development indicators for organic family farming. Proceedings 19th Triennial Congress of the IEA (pp. 1-8). Melbourne : Congress of the IEA.

Schmerler, C. (2006). Value Chain Promotion: Experiences with Organic Rice from Cabodia. GTZ Rural Development Programme, Phnom Penh, Cambodia. . Phnom Penh, Cambodia.

Scialabba, N. a. (2002). Organic Agriculture, Environment and Food Security. Rome: Food and Agriculture Organisation of the United Nations.

Sellmer, J., Ostiguy, N., Hoover, K., \& Kelley, K. (2004). Assessing the integrated pest management practices of pennsylvania nursery operations. Hort Science, 39(2), 297-302.

Setboonsarng, S. (2006). Organic Agriculture, Poverty Reduction and the MDGs.

Smith, T. A., Huang, C. L., \& Lin, B. H. (2009). Does price or income affect organic choice? Analysis of US fresh produce users. Journal of Agricultural and Applied Economics, 41(3), $32-41$.

Soda, O. (2006). Philosophy of Agricultural Science: A Japanese Perspective (Japanese Society Series). Japan: Trans Pacific Press.

Sudheer, P. (2011). Economics of Organic Farming: A Study in Andhra Pradesh. 
ISSN: 2362-1303 (Paper) | elSSN: 2362-1311(Online)

JOURNAL OF ADVANCED ACADEMIC RESEARCH (JAAR)

Jan 2016

Sullivan, P. (2002). Drought Resistant Soil. Retrieved from http://attra.ncat.org

Swezey, S. L., Goldman, P., Bryer, J., \& Nieto, D. (2007). Six-year comparison between organic, IPM and conventional cotton production systems in the northern san joaquin valley, california. Renewable Agriculture and Food Systems, 22(1), 30-40.

Tamang, S., Dhital, M., \& Acharya, U. (2011, 3 June). Status and scope of organic agriculture in Nepal. Kathmandu: FOOD AND SUSTAINABLE AGRICULTURE INITIATIVE FORESTACTION, NEPAL.

Tamang, S., Dhital, M., \& Acharya, U. (2011, 3 June). Status and scope of organic agriculture in Nepal. Kathmandu: FOOD AND SUSTAINABLE AGRICULTURE INITIATIVE FORESTACTION, NEPAL.

Taylor, J. (2000). So Now they are going to measure empowerment. CDRA.

The Hartman Group. (2006). Who's buying organic? Demographics 2006.

The World Farmers' Organisation (WFO). ( 2013, Nov 29). Retrieved February 27, 2016, from The World Farmers' Organisation (WFO): http://www.wfo-oma.com/press/familyfarming-an-organizational-model-to-overcome-the-crisis-english.html

Thill, D. C., Lish, J. M., Callihan, R. H., \& Bechinski, E. J. (1991). Integrated weed managementa component of integrated pest-management - a critical-review. Weed Technology, 5(3), 648-656.

UNESCAP. (2002). Organic Agriculture and Rural Poverty Alleviation: Potential and best practices in Asia. Bangkok: United Nations Economic and Social Commission for Asia and the Pacific.

WED. (2006). Wellbeing in Developing Countries: Conceptual Foundations of the WeD Programme. Bath, UK: ESRC Research Group on Wellbeing in Developing Countries.

Whatmore, S., Stassart, P., \& Renting, H. (2003). What's alternative about alternative food networks? Environment and Planning, 35, 389-391.

Wheeldon, J. (2010, April). Mapping Mixed Methods Research: Methods, Measures and Meaning. Journal of Mixed Methods Research, 4(2), 87-102.

Wilairat, N. (2010). Policies to Improve Organic Agriculture:Prospects to Meet an Agrarian, Ecological, or Resource Vision. Pomona College.

Willer, H. a. (2009). The World of Organic Agriculture. Statistics and Emerging Trends 2009 (Eds.). Frick, Switzerland: IFOAM, Bonn, and FiBL. 
ISSN: 2362-1303 (Paper) | elSSN: 2362-1311(Online)

Wilson, R. S., Hooker, N., Tucker, M., LeJeune, J., \& Doohan, D. (2009). Targeting the farmer decision making process: A pathway to increased adoption of integrated weed management. Crop Protection, 28(9), 756-764.

Yiridoe, E. K., Bonti-Ankomah, S., \& Martin, R. C. (2005). Comparison of consumer perceptions and preference toward organic versus conventionally produced foods: A review and update of the Literature. Renewable Agriculture and Food Systems, 20(4), 193-205. 